\title{
The Entrepreneurial Opportunities available for Youth in Shivamogga - A Study
}

\author{
Shivakumara K. ${ }^{1}$ and Hemantha S. R. ${ }^{2}$ \\ ${ }^{1}$ Lecturer, Department of Commerce and Management, Sahyadri Commerce and Management \\ College, Shivamogga, Karnataka, India. \\ ${ }^{2}$ Assistant Professor, Department of Commerce and Management, STJ College for Women, \\ Chikmagalur, Karnataka, India.
}

CITATION: Shivakumara, K. and Hemantha, S. R. (2020), "The Entrepreneurial Opportunities available for Youth in Shivamogga - A Study", MERC Global's International Journal of Management, Vol. 8, Issue 1, pp. 35-39.

ARTICLE HISTORY: Submitted: September 07, 2019, Revision received: September 29, 2019, Accepted: October 20, 2019

ARTICLE TYPE: Research paper

\begin{abstract}
The main purpose of this research study is to find out the process of designing, launching and running a new business, which is often initially a small business in the Malnad region. This study explains the views on entrepreneurship by the youth of Shivamogga and the possible reasons for being unemployed and what measures, if taken can help them sustain or secure self-employment. It also talks about the sectors wherein the growth of entrepreneurship has seen the most and what sectors would the youth prefer in starting their own enterprise and if whether they still hope to get a job of their choice.
\end{abstract}

KEYWORDS: Unemployment, Shivamogga, Opportunities, Entrepreneurship.

\section{BIBLIOGRAPHY}

1. Bengaluru may top the funding scenario (2018), Bengaluru may top the funding scenario, but Hyderabad mounts strong challenge, available at: https://yourstory.com/2018/02/bengaluru-may-top-fundingscenario-hyderabadgearing-take-lead/, accessed on 5 Dec. 2018.

2. IPAN (2018), The Start-Up Ecosystem in India - Present Scenario - IPAN, available at: http://www.ipan.in/the-start-up-ecosystem-in-india-present-scenario/, accessed on 5 Dec. 2018.

3. Phadnis, S. (2018), Bengaluru, Delhi top in startup funding - Times of India, The Times of India, available at: https://timesofindia.indiatimes.com/business/indiabusiness/bengaluru-delhi-top-in-startupfunding/articleshow/64926284.cms, accessed on 5 Dec. 2018.

4. The Hindu (2018), Unemployed youth launch app to help graduates find jobs, available at: https://www.thehindu.com/news/national/karnataka/unemployed-youth-launch-appto-help-graduatesfind-jobs/article19984580.ece, accessed on 5 Dec. 2018. 